\title{
Retraction
}

\section{Retracted: Estimation of Response Functions Based on Variational Bayes Algorithm in Dynamic Images Sequences}

\author{
BioMed Research International \\ Received 14 June 2017; Accepted 14 June 2017; Published 20 June 2017 \\ Copyright (C) 2017 BioMed Research International. This is an open access article distributed under the Creative Commons \\ Attribution License, which permits unrestricted use, distribution, and reproduction in any medium, provided the original work is \\ properly cited.
}

BioMed Research International has retracted the article titled "Estimation of Response Functions Based on Variational Bayes Algorithm in Dynamic Images Sequences" [1]. The article was previously submitted to arXiv as: Ondřej Tichý, Václav Šmídl, "Non-parametric Bayesian Models of Response Function in Dynamic Image Sequences," arxiv, 2015 (https://arxiv.org/abs/1503.05684).

\section{References}

[1] B. Shan, "Estimation of response functions based on variational bayes algorithm in dynamic images sequences," BioMed Research International, vol. 2016, Article ID 4851401, 9 pages, 2016. 